\title{
EDITORIAL Mastozoología Sudamericana, por Mastozoólogos Sudamericanos
}

Robert D. Owen ${ }^{1}$

América del Sur está clasificado como un continente de mediano tamaño (más pequeño que América del Norte, más grande que la Antártica), que comprende alrededor del $12 \%$ de la superficie terrestre total del mundo, pero incluyendo sólo el $6 \%$ de la población humana del mundo. Sin embargo, atraviesa casi 70 grados de latitud, que se extiende desde los trópicos del hemisferio norte (casi $13^{\circ} \mathrm{N}$ ) para el hemisferio sur sub-antárticas $\left(56^{\circ} \mathrm{S}\right.$, a unos 20 grados más al sur que el continente africano). En elevación es clasificado de $-105 \mathrm{~m}$ a $6,960 \mathrm{~m}$, con una enorme cadena montañosa que se extiende a lo largo del continente. La precipitación anual varía entre $0 \mathrm{~mm}$ (algunas estaciones en el Desierto de Atacama) a más de 3,200 mm (varias localidades en la cuenca del Amazonas). Tres grandes cuencas fluviales (Orinoco, Amazonas y La Plata) drenan la mayor parte de la superficie terrestre, formando barreras biogeográficas y áreas de endemismo. Las grandes ecoregiones boscosas incluyen la Selva Amazónica y el complejo de Bosque Atlántico, y el continente es atravesado de noreste a suroeste por una semiárida a árida faja incluyendo los ecorregiones de la Caatinga, Cerrado, Pantanal, Gran Chaco, Pampa, y Patagonia.

Estos altos niveles de diversidad geográfica y climática son reflejados en un alto nivel de diversidad biótica, incluyendo la de los mamíferos. Varios linajes relativamente antiguos (Ej. xenartros, roedores hystricomorph, marsupiales) han sido sometidos a la diversificación generalizada en el continente, ya que tienen algunas apariciones más recientes (roedores muroides, carnívoros). Todos contribuyen a la riqueza de especies de mamíferos y diversidad por la cual América del Sur es reconocida. A pesar de que la fauna mastozoológica de América del Sur ha sido sujeta a observaciones e investigaciones por varios siglos, el patrón histórico ha sido lo que a menudo se ha visto en el sur global - la mayoría de los estudios e informes que se realizaron por naturalistas o biólogos procedentes de Europa y América del Norte, con ejemplares que residen en los museos de esas regiones, y las publicaciones resultantes, rara vez llega a los académicos y otros públicos interesados en los países donde se realizaron los estudios. Sin embargo, desde aproximadamente la mitad del siglo 20, biólogos sudamericanos han comenzado a contribuir más activa y visiblemente al cumulo de conocimientos.

En las últimas décadas del siglo 20 se han visto la formación de sociedades nacionales de mastozoólogos en varios países, convocando a reuniones profesionales.

'Department of Biological Sciences, Texas Tech University. Lubbock, Texas, USA 79409; and Raúl Casal 2230 c/ Pizarro, Asunción, Paraguay 1371. Email: rowen@tigo.com.py 
Además, los departamentos de graduados universitarios y las instalaciones de museos se han fortalecido y se entrena a un número creciente de jóvenes especialistas en mastozoología. Por lo tanto, muchos más biólogos están siendo entrenados en sus propios países o en países vecinos, en lugar de emprender el costoso proceso de formación de postgrado en Europa o América del Norte, por lo general en un idioma extranjero. Es importante destacar que esto hace que este campo de la biología sea más accesible a los estudiantes con recursos personales o familiares limitados.

Actualmente en América del Sur el campo de la mastozoología ha alcanzado un nivel de madurez demográfica. Algunos de los investigadores anteriores han fallecido, un número de la "vieja generación" están a punto de jubilarse, una "generación intermedia" está en el pico de su productividad profesional, y muchos biólogos más jóvenes están empezando lo que promete ser carreras productivas en mastozoología.

La mayoría de los lectores de Therya conocen a algunos de estos biólogos de América del Sur, pero yo (como muchos mastozoólogos en México y los EE.UU.) no tenía la idea de la cantidad, diversidad y vitalidad de la mastozoología sudamericana hasta que empecé a trabajar y vivir en América del Sur. Pocos mastozoólogos sudamericanos asisten a reuniones profesionales en América del Norte y viceversa. De ahí que las conexiones entre colegas mastozoologos y sus comunidades de las dos Américas no son tan numerosas o fuertes como desearíamos que fueran.

Cuando me pidieron editar esta Sección Especial de Therya, rápidamente se me ocurrió que esta era una oportunidad para poner unos pocos ejemplos actuales de la mastozoología de América del Sur en manos de colegas norteamericanos. Varias ideas básicas me guiaron en la determinación de a quién invitar. Cada autor invitado es originario de América del Sur, y vive y trabaja en América del Sur. En otras palabras, no se invitó a ningún inmigrante como yo, ni a emigrantes. Buscando la diversidad geográfica en todo el continente, invité al menos a un especialista en mamíferos de cada país de América del Sur (excepto Guyana y Surinam) a contribuir con un manuscrito. En varios casos, el autor/a vive y trabaja en un país distinto al de su origen, contribuyendo así al cruzamiento de ideas. En numerosos casos, el artículo reporta sobre trabajo realizado en un país distinto del de origen o residencia del autor, lo que refleja la movilidad y el deseo de aprender y trabajar en una variedad de ambientes, demostrado por muchos mastozoólogos sudamericanos.

Los autores invitados tuvieron la libertad de incluir a coautores, ya sea sudamericano o no. Mientras escribo esto, con ocho manuscritos aceptados para la Sección Especial, uno tiene un solo autor, y el resto tiene uno o más coautores; de aproximadamente 16 coautores en total, tres no son sudamericanos. Siguiendo la política editorial de Therya, los manuscritos serían aceptados en español o inglés, por lo que se excluyeron algunas lenguas oficiales de los países de América del Sur: portugués (Brasil), guaraní (Paraguay), el aymara y el quechua (Perú) y más de 35 idiomas no europeos reconocidos como oficial en Bolivia.

Quería una diversidad de etapas de carrera representados entre los autores. La mayoría de los autores invitados están bien establecidos y con muy activas y productivas carreras, y unos pocos de ellos son probablemente mejor descrito como "viejos respetados" (voy a dejar que el lector decida a quienes me refiero). Me complace señalar que entre los autores también contamos con biólogos jóvenes (algunos aún en 
programas de postgrado) y para-biólogos (que carecen de entrenamiento formal, pero muy valiosos en muchos proyectos)

No hubo restricciones en el tema de investigación, aparte de que la atención debe centrarse en los mamíferos de América del Sur. Sin embargo, se esperaba una diversidad de taxones y de áreas de investigación representadas entre los artículos y los autores seleccionados a ser invitados, basado en parte en sus publicaciones y de lo que conocía que los mismos estaban trabajando en la actualidad. Tres de estos artículos son sobre los murciélagos, tres sobre roedores, uno sobre marsupiales y uno incluye ambos roedores y marsupiales; tres son trabajos en sistemática (incluyendo la descripción de una nueva especie), dos son sobre ecología o comportamiento, uno en conservación, y uno o dos son revisiones generales; la mayoría son estudios sobre mamíferos Recientes, y uno compara la fauna de pequeños mamíferos Holocénicos y Recientes. En definitiva, este conjunto de artículos representa una diversidad de áreas de investigación activas en biología de los mamíferos de América del Sur.

Hay un gran número de buenos científicos que trabajan de manera activa y productiva en mastozoología de América del Sur, y animo a los lectores de este número de Therya a mirar a través de la Literatura Citada secciones de estos artículos, para hacerse una idea de la cantidad de trabajos que existen en América del Sur, y la cantidad, amplitud y profundidad de las publicaciones procedentes de América del Sur que están contribuyendo ampliamente al creciente conocimiento sobre la fauna de mamíferos de América del Sur.

Más allá de traer a su atención al trabajo de los especialistas en mamíferos de América del Sur, espero que la publicación de estos artículos en Therya dé lugar a relaciones de trabajo más fuertes y numerosas entre colegas mastozoólogos sudamericanos y norteamericanos, en particular entre los más jóvenes «cohortes» de nuestra profesión estudiantes graduados y en las primeras etapas de sus carreras. Al inicio de mi carrera, me beneficié enormemente ampliando mis horizontes trabajando con numerosos colegas de México, muchos de los cuales ahora los cuento entre mis mejores amigos. Más recientemente, he continuado creciendo profesionalmente y llegando a ser un mejor mastozoólogo (y mejor persona, espero) a través de la colaboración y la amistad de los colegas de toda América del Sur, varios de los cuales están entre los autores de estos artículos. Espero que la lectura de uno o más de los artículos de esta Sección Especial será tan interesante y valioso para usted, como lo fue para mí la coordinación y edición de los mismos.

\section{Agradecimientos}

Agradezco muy especialmente a Mike Kennedy y a Gary Schnell, quienes fueron los primeros en llevarme a realizar trabajos de campo en México, donde fui cautivado por la mastozoología de campo y por el Neotrópico y donde fui sumergido en la cultura de América Latina. Esto cambió mi vida para siempre. Durante los años que trabaje en México, Cornelio Sánchez-Hernández y María de Lourdes Romero-Almaraz siempre me dieron un hogar in Ciudad de México y Chamela, así también lo hizo Ricardo LópezWilchis y su familia en Ciudad de México y Cuauhtémoc. Este proyecto editorial fue parcialmente apoyado por el Consejo Nacional de Ciencia y Tecnología (CONACYTParaguay), a través del Programa Nacional de Incentivos a Investigadores (PRONII). Lucy 
Aquino, Cesar Balbuena, Maggie Mieres y Paul Smith me ayudaron a organizar y a expresar mis ideas, en inglés y español. Finalmente, agradezco a Sergio Ticul Álvarez Castañeda por su invitación y estímulo para la realización de esta Sección Especial de Therya.

\section{EDITORIAL}

South American Mammalogy, by South American Mammalogists

South America is in the middle of the continents when ranked by size (smaller than North America, larger than Antarctica), comprising around $12 \%$ of the world's total landmass, but including only $6 \%$ of the world's human population. However, it traverses nearly 70 degrees of latitude, extending from the northern hemisphere tropics (almost $13^{\circ} \mathrm{N}$ ) to the southern hemisphere sub-antarctic $\left(56^{\circ} \mathrm{S}\right.$, about 20 degrees farther south than the African continent). In elevation it ranges from $-105 \mathrm{~m}$ to $6,960 \mathrm{~m}$, with an enormous mountain range extending the length of the continent. Average annual precipitation varies from essentially $0 \mathrm{~mm}$ (some stations in the Atacama Desert) to over 3,200 $\mathrm{mm}$ (several localities in the Amazon Basin). Three large river basins (Orinoco, Amazon, and La Plata) drain the majority of the land area, forming both biogeographic barriers and areas of endemism. Large forested ecoregions include the Amazon Forest and the Atlantic Forest complex, and the continent is traversed from northeast to southwest by a semiarid to arid band including the Caatinga, Cerrado, Pantanal, Gran Chaco, Pampas, and Patagonian ecoregions.

These high levels of geographic and climatic diversity are reflected in high levels of biotic diversity, including that of mammals. Several relatively old lineages (e.g., xenarthrans, hystricomorph rodents, marsupials) have undergone widespread diversification on the continent, as have some more recent arrivals (muroid rodents, carnivores), all contributing to the mammalian species richness and diversity that South America is renowned for. Although the South American mammalian fauna has been the subject of observations and investigations for several centuries, the historical pattern has been that seen often in the global south--a majority of the studies and reports were done by naturalists or biologists from Europe and North America, with specimens residing in museums of those regions, and resulting publications seldom reaching the academics and other interested audiences in the countries where the studies were made.

However, since roughly the middle of the 20th century, South American biologists have begun contributing more vigorously and visibly to the accumulation of knowledge. The latter decades of the 20th century have seen the formation of national societies of mammalogists in several countries, holding professional meetings. Moreover, university graduate departments and museum facilities have been strengthened, and are training a growing number of younger mammalogists. Thus, many more new biologists are now being trained in their own or neighboring countries, rather than undertaking the expensive process of graduate training in Europe or North America, generally in a foreign language. Importantly, this makes the field more accessible to students with limited personal or family resources. 
Currently in South America the field of mammalogy has achieved a level of demographic maturity. Some of the earlier workers have passed on, a number of "older generation" are nearing retirement, a "middle generation" is at the peak of their productivity, and many younger biologists are beginning what promise to be productive careers in mammalogy.

Most of the readers of Therya know a few of these South American biologists, but I (like many mammalogists in Mexico and the US) was unaware of the extent, diversity, and vitality of South American mammalogy until I began working extensively, and then living, in South America. Few South American mammalogists attend professional meetings in North America, and vice versa. Thus the collegial connections between the mammalogists and their communities of the two Americas are not as numerous or strong as we might wish them to be. When I was asked to edit this Special Section of an issue of Therya, it quickly occurred to me that this was an opportunity to place a few examples of current South American mammalogy in the hands of their North American colleagues.

Several basic ideas guided me in determining whom to invite. Each invited author is originally from South America, and is living and working in South America. In other words, no immigrants like myself were invited, nor were any emigrants. Seeking geographic diversity across the continent, I invited at least one mammalogist from each South American country (except Guyana and Suriname) to contribute a manuscript. In several cases, the author is living and working in a country other than that of his/her origin, thus contributing to the cross-fertilization of ideas. In a number of cases, the article reports on work done in a country other than the author's origin or residence, reflecting the mobility and the desire to learn and work in a variety of environments, shown by many South American mammalogists.

The invited authors were free to invite coauthors, whether South American or not. As I write this, with eight manuscripts accepted for inclusion in this Special Section, one is single-authored and the remainder have one or more coauthors; of approximately 16 coauthors in total, three are non-South Americans. Following Therya editorial policy, manuscripts would be accepted in Spanish or English; thus some official languages of South American countries were excluded: Portuguese (Brazil), Guarani (Paraguay), Aymara and Quechua (Peru) and over 35 non-European languages recognized as official in Bolivia.

I wanted a diversity of career stages represented among the authors. The majority of invited authors are well established and in very active and productive careers, and a couple are probably best described as "respected elders" (I'Il let the reader decide which those are). I am pleased to note that a number of the author lines also include younger biologists (some still in graduate programs) and parabiologists (lacking formal training, but invaluable in many projects).

There was no restriction on research topic, other than that the focus should be on South American mammals. Nevertheless, I hoped a diversity of taxa and of research areas would be represented among the articles, and selected authors to be invited based in part on their publication record and what I knew them to be working on currently. Three of these articles are about bats, three about rodents, one about marsupials, and one includes both rodents and marsupials; three are systematic papers (including description of a new species), two are ecology or behavior, one is conservation, and one or two are general reviews; most are studies of Recent mammals, and one compares Holocene and 
Recent small mammal faunae. In short, this assemblage of articles does represent a diversity of active research areas in South American mammalogy.

There are a great many good scientists working actively and productively in South American mammalogy, and I encourage readers of this issue of Therya to look through the Literature Cited sections of these articles, to gain an impression of how many South American workers there are, and the quantity, breadth, and depth of publications from South America which are contributing extensively to the growing body of knowledge on the South American mammal fauna.

Beyond bringing the work of South American mammalogists to your attention, I hope that publication of these articles in Therya will result in stronger and more numerous collegial and working relationships between South American and North American mammalogists, in particular among the younger "cohorts" of our profession--current graduate students and recently graduated professionals in the early stages of their careers. In the early stages of my career, I profited greatly from expanding my horizons in working with a number of colleagues in Mexico, several of whom I now count among my best friends. More recently, I have continued to grow and become a better mammalogist (and better person, I hope) through the collaboration and friendship of colleagues throughout South America, several of whom are among the authors of these articles. I hope that reading one or more of the articles in this Special Section will be as interesting and valuable to you, as my coordination and editing of them has been for me.

I especially thank Mike Kennedy and Gary Schnell, who first took me to do field work in Mexico, where I was captured by field-based mammalogy and by the Neotropics, and was introduced to Latin America. This changed my life, for the better. During the years I worked in Mexico, Cornelio Sánchez-Hernández and María de Lourdes Romero-Almaraz always gave me a home in Mexico City and Chamela, as did Ricardo López-Wilchis and his family in Mexico City and Cuauhtémoc. This editorial project was partially supported by the Consejo Nacional de Ciencia y Tecnología (CONACYT-Paraguay), through the Programa Nacional de Incentivo a Investigadores (PRONII). Lucy Aquino, Cesar Balbuena, Maggie Mieres, and Paul Smith all helped me to organize and express my thoughts, in both English and Spanish. Finally, I thank Sergio Ticul Álvarez Castañeda for his invitation and encouragement for this Special Section of Therya. 